\title{
AUDIT QUALITY: THE IMPACT OF EXPERTISE, INDEPENDENCE AND ETHICS OF PROFESSIONAL ACCOUNTANT A CROSSSECTIONAL STUDY
}

\author{
Adam Ramdani \\ Sekolah Tinggi IImu Ekonomi Pasundan, Bandung, Indonesia. \\ E-mail: adam@stiepas.ac.id
}

\begin{abstract}
This study aims to determine the effect of expertise, independence, and ethics on audit quality at the Inspectorate of West Java Province. The study in the initial review of this study found that the audit quality is shown in the opinion given by the examiner, including the opinion "Reasonable Without Exception" is a professional audit statement regarding the "fairness" of the financial statements, not a "guarantee" that no fraud was encountered or the possibility of the occurrence of fraud. Fraud in the future also on the problem of procurement of goods and services that cause indications of regional losses, management of accounts that are not following the provisions, causing potential fraud, management of fixed assets that are still problematic both in terms of administration and utilization and the problem is that the value is still found to be immaterial so that the Audit Board of the Republic of Indonesia gives an opinion "Reasonable Without Exception" (RWE). In the first stage of this research, namely, test the validity and reliability of all valid and reliable variables. In the second stage of conducting a correlation analysis for Expertise, Independence and Ethics on Audit Quality, showing a significant correlation, the relationship between Expertise and Audit Quality obtained a result of 0.813. Independent Relationship with Audit Quality obtained results of 0.751 , and the result of Ethics Relationship with Audit Quality obtained results of 0.812. In the third stage, partial regression analysis for all variables proved to be significant, and it was found that the regression coefficient value of Expertise on Audit Quality obtained the result of 0.411 . The independent regression coefficient value on Audit Quality is 0.235 , and the Ethics regression coefficient on Audit Quality is 0.403. Likewise, in the fourth stage, simultaneous multiple regression analysis of expertise, independence, and ethics has a significant effect on Audit Quality with a total effect of $83.7 \%$.
\end{abstract}

Keywords: expertise, independence, ethics, audit quality.

\section{INTRODUCTION}

The main challenge for the Indonesian nation is to prepare existing individuals to become solid and qualified human resources, not only to face current conditions but in the future to be able to face challenges that arise in the future. In this context, education plays 
an essential role in creating superior, resilient, and ready to compete for human resources in any condition, which is an aspect of intangible assets that plays an important role. (Sidharta \& Affandi, 2016)

In the current democratic era, the government must be more transparent and accountable for managing state monetary funds. Public demands on the administration of government demanding the realization of good and clean governance are increasing, which requires competent government officials to carry out reliable internal control functions and an excellent internal control system in accountability for the use of funds for the implementation of government which ensures the implementation of activities can be evenly distributed throughout the public sector and has complied with the established policies and plans and the applicable provisions economically, efficiently, and effectively. (Motubatse, Ngwakwe \& Sebola, 2017)

The program to increase supervision and accountability of state apparatus is one of the government programs that aim to improve and streamline the monitoring and auditing system and the accountability system for the performance of government agencies in realizing a clean apparatus. The target to be achieved is the realization of a monitoring and auditing system and a performance accountability system within the state apparatus. This is closely related to the task of an auditor to assess and examine financial statements to reassess existing government reports. (Sutaryo, Naviantia \& Muhtar, 2020) This assessment can be input for the government regarding financial matters or its financial statements so that all forms of misstatements can be resolved optimally. (Ultimate, Ibtida \& Avrian, 2018).

Provincial, Regency/Municipal Inspectorates have the functions of planning supervision programs, formulating policies, and facilitating supervision, inspection, investigation, testing, and assessment of supervisory tasks following government regulation No. 41 of 2007 concerning Regional Apparatus Organizations.

However, in reality, the audit quality is shown in the opinion given by the examiner, including the "Reasonable Without Exception" opinion is a professional audit statement regarding the "fairness" of financial statements, not a "guarantee" that no fraud will be encountered or the possibility of fraud in the future. Also on the problem of procurement of goods and services that give rise to indications of regional losses, management of accounts that are not following the provisions that lead to potential fraud, management of fixed assets that are still problematic both in terms of administration and utilization and the problem is still found to be of immaterial value so that the Audit Board of the Republic of Indonesia gives an opinion "Reasonable Without Exceptions" (RWE)

The Inspectorate as an internal supervisory apparatus for the West Java provincial government, which has a controlling function, is required to be able to act as an auditing/supervising agency providing early warning systems, consulting partners, and being able to become quality assurance to realize good governance into clean governance. (Adams, 1994; Andrews, 2010 \& Afiah \& Rahmatika, 2014)

Increased supervision can be done by increasing the intensity and quality of the implementation of supervision and audit by arranging and improving institutional structure policies, independent, effective, efficient, transparent, and measurable 
supervision procedures, and following up on supervisory findings to improve a more comprehensive supervisory work environment. (Head, 2012) In addition, by developing the implementation of performance-based supervision and developing the professionalism of examiners by developing and improving the information system of the Government Functional Supervisory Apparatus (GFSA) (Lee, Su, Tsai, Lu \& Dong, 2016) and improving the quality of information resulting from supervision, code of ethics and audit standards, conduct periodic evaluations of the performance and findings of supervision results as well as improve the working environment among law enforcement officers to follow up on the findings of both internal and external supervision. (Barzelay, 1997; Radcliffe, 2008).

The results of a quality internal audit indicate reasonable and responsible supervision and management of government finances. However, suppose the quality of the internal audit is low. In that case, it gives government agencies leeway to make mistakes and irregularities in the budget, which results in the risk of lawsuits against government officials. Therefore, the internal control function in the government's internal audit is carried out by the Government Internal Supervisory Apparatus (GISA), namely the Inspectorate.

Auditors strive to maintain a high degree of independence to maintain users' confidence who depend on their reports. Auditors who report the company's financial statements are often called Independent Auditors. (Prawitt, Smith \& Wood, 2009) Although the company pays these auditors, they are usually independent enough to perform reliable audits by users. Even internal auditors - employed by the audited firm typically report directly to top management and the board of directors, keeping auditors independent of the operating unit being audited (Arens, Randal, Mark \& Chris, 2017). The first general standard states that the audit must be carried out by one or more persons who have sufficient technical expertise and training as an auditor.

Competence or expertise is a skill and ability in carrying out a job or profession. (Roussy \& Brivot, 2016) Competent people mean people who can carry out their work with good quality results. In a broad sense, competence includes mastery of sufficient knowledge and skills and has the appropriate attitude to carry out the work or profession. (Eilifsen, Messier, Glover \& Prawitt, 2014)

The Regulation of the Minister of State for Administrative Reform No. 05 of 2008 indicates that auditors must have the necessary knowledge, skills, and other competencies to carry out their responsibilities. The independence of public accountants is as vital as expertise in accounting practices and audit procedures that every public accountant must possess. Independence, in reality, will exist if the Auditor can maintain an impartial attitude during the audit. (Ciger, 2020) Independence is due to professional care means that auditors plan and perform their duties with the skills and care expected of professional accountants. (Eilifsen, Messier, Glover \& Prawitt, 2014)

One thing that distinguishes the public accounting profession from other professions is the responsibility of the public accounting profession to protect the public interest. Therefore, the responsibilities of the public accounting profession are not only limited to 
the interests of the client, but when acting, they must comply with and apply all the basic principles and codes of professional ethics that have been determined.

In carrying out the audit task, the Auditor of the State Audit Board determines based on Law no. 2 of 2007 concerning the code of ethics, namely the norms that every member and examiner must obey while carrying out their duties. The Auditor must comply with the established code of ethics. The audit implementation must refer to the audit standard, and the Auditor must comply with the code of ethics, which is an integral part of the audit standard.

Auditors perform their duties under their rights and obligations, as well as being able to maintain good auditor attitudes, will improve audit quality. (Zhukun, Wang \& Zhang, 2018) The results of an increase in audit quality can show an auditor who is capable and good at carrying out his audit duties. The Auditor's role is to collect and analyze sufficient and relevant audit evidence and report audit findings or problems found during the audit. This is closely related to the task of an auditor to assess and examine financial statements to reassess existing government reports. (Bedard, Johnstone \& Smith, 2010) This assessment can be an input for the government regarding financial matters or its financial statements so that all forms of misstatements can be resolved optimally.

Audit quality is the probability that an auditor finds and reports about a violation in his client's accounting system. (Ciger, 2020) Quality of audit results also means reporting on weaknesses in internal control and compliance with regulations, responses from responsible officials, disclosing prohibited information confidential, distributing audit reports, and following up on the Auditor's recommendations following the laws and regulations. (Nor, Hudaya \& Novriyandana, 2019)

The Auditor's competence to find and eliminate material misstatements and manipulations in financial statements affects audit quality. It also proves that four factors affect audit quality: budget scope, incompetence, evaluating transactional critically, and not independent. Incompetence and independence are factors that affect audit quality (Roussy \& Brivot, 2016). Auditor independence is a determining factor in the public accounting profession. Without independence, the task of audit detection to find material misstatements is questionable because biased reports have a low influence on audit quality. (Kallunki, Kallunki, Niemi, Nilsson \& Aobdia, 2019) Audit quality is a condition where an auditor will find and report non-conformances to principles that occur in his client's accounting reports. (Pamungkas, Ibtida \& Avrian, 2018; Sitorus, Hendratono \& Fransisca, 2020) Therefore, independence, auditor ethics, competence, and audit standards are seen as related to the audit quality produced by the Auditor.

This study examines the influence of Expertise, Independence, and Ethics on Audit Quality at the Inspectorate of West Java Province. The Inspectorate is one component of the West Java Provincial Government that carries out financial management audits to minimize state losses and improve financial administration in every activity carried out by local governments' agencies within the West Java Provincial Government. 


\section{METHOD}

This study uses quantitative methods using descriptive and verification analysis. The sample used is as many as 70 respondents. The data quality test uses validity and reliability tests, while data testing using multiple regression test data analysis techniques.

This study aims to determine the effect of expertise, Independence, and ethics on audit quality. At the initial stage, this research validates instruments on expertise consisting of Knowledge, Skill, and Attitude, instrument validation on Independence consisting of Independence in fact, and Independence in appearance. Instrument validation on Ethics consisting of integrity, objective, confidentiality, and competence, and instrument validation on audit quality consisting of timely, complete, accurate, objective, convincing, unambiguous, and concise. Then perform reliability tests for expertise, Independence, ethics, and audit quality.

In this study, the researcher uses multiple regression analysis to predict how the dependent variable's condition (up and down) will be if two or more independent variables as predictor factors increase and decrease in value.

\section{RESULTS AND DISCUSSION}

The research was carried out at the West Java inspectorate. The sampling method was based on the simple randon sampling method, which is simply because the sampling of members of the population is done randomly without regard to the strata in the population. To test the validity, reliability, and correlation between variables obtained the following results:

Table 1 . The results of the calculation of validity, reliability, and correlation between research variables

\begin{tabular}{|l|c|c|c|c|c|c|}
\hline Variabel & $\mathrm{r}$ & $\begin{array}{c}\text { Crobach } \\
\text { alpha }\end{array}$ & Expertise & Independence & Ethics & $\begin{array}{c}\text { Audit } \\
\text { Quality }\end{array}$ \\
\hline Expertise & $\begin{array}{c}0,305- \\
0,596\end{array}$ & 0.729 & 1,000 & & & \\
\hline Independence & $\begin{array}{c}0,311- \\
0,649\end{array}$ & 0.707 & 0,629 & 1,000 & & \\
\hline Ethics & $\begin{array}{c}0,312- \\
0,492\end{array}$ & 0.780 & 0,631 & 0,638 & 1,000 & \\
\hline Audit Quality & $\begin{array}{c}0,301- \\
0,640\end{array}$ & 0.785 & 0,813 & 0,751 & 0,812 & 1,000 \\
\hline
\end{tabular}

From Table 1 above, it can be concluded that the validity test results for each indicator of the skill variable show valid results. This is because the value of the validity test results 
for each indicator is more than the r-value of 0.300. as well as independent variables, ethics, and audit quality variables. Table 1 above shows that the four variables tested have a reliability test result of more than 0.700 , meaning that the four variables are declared reliable. The results of the correlation analysis between Expertise, independence, ethics, and audit quality show that the relationship between Expertise and Audit Quality is 0.813, which means that the relationship between Expertise and Audit Quality is in a very strong category. Independent Relationship with Audit Quality obtained a result of 0.751, which means that the relationship between Expertise and Audit Quality is in a strong category. The relationship between Ethics and Audit Quality is 0.812, which means that Expertise and Audit Quality are in a very strong category. The results of multiple Linear regression analysis obtained results such as table 2 below.

Table 2. Multiple regression calculation results

\begin{tabular}{|l|c|c|c|c|}
\hline \multicolumn{1}{|c|}{ Variabel } & Beta & Zero Order & $\mathrm{t}$ & P value \\
\hline Expertise & 0,411 & 0,813 & 5,945 & 0,000 \\
\hline Independence & 0,235 & 0,751 & 3,372 & 0,001 \\
\hline Ethics & 0,403 & 0,812 & 5,768 & 0,000 \\
\hline R Square $=, 837$ & & & \\
F $=113,268$ & & & \\
Sig $=0,000$ &
\end{tabular}

Based on the study results as shown in table 2, it can be seen that Expertise influences Audit Quality. It can be seen that the influence of the independent variable is partial (X1). Expertise on the dependent variable Y (Quality Audit) at the Inspectorate of West Java Province partially obtained from Beta $x$ Zero-order is $0.411 \times 0.813=0.334$ or $33.4 \%$. At the time of testing the hypothesis to determine the effect of Expertise on Audit Quality, Expertise (X1) count $(5.945)<\mathrm{t}$ table $(1.6676)$ value sig $(0.00)<$ alpha $(0.05)$ so Ho is rejected, which means that the Expertise variable partially affects significantly.

The results of this study are reinforced by the results of previous research conducted by Gamayuni (2018) that Expertise has a significant effect on auditor quality with a significant value of 0.000 with an error rate (alpha) of 0.05 . Audit quality means how to detect audits and report material misstatements in the financial statements. The detection aspect reflects the competence of the auditor, while reporting is a reflection of ethics or auditor integrity, especially independence. (Arens, Randal, Mark \& Chris, 2017).

The Influence of Independence on Audit Quality. Based on the study results as shown in table 2, it can be seen that it influences Audit Quality. It is known that the influence of the independent variable X2 (Independence) on the dependent variable $\mathrm{Y}$ (Audit Quality) at the Inspectorate of West Java Province was partially obtained from Beta $\times$ Zero-order, namely $0.236 \times 0.751=0.177$ or $17.7 \%$. At the time of testing the hypothesis to determine the effect of Expertise on Audit Quality, the value of Independence (X2) was obtained, the value of $t$ count (3.372) < t table (1.6676) sig (0.01) 
$<$ alpha (0.05) so that Ho was rejected, which means that partially the Independence variable significant effect.

The results of this study are supported by the results of previous studies that have been carried out. In addition, the results of this study are supported by the results of previous studies that have been carried out by Aliu, Okpanachi \& Mohammed (2018) in the results of their independent research that it significantly affects the quality of auditors with a significant value of 0.000 which is smaller than the level of significance of $0.050(0.000<$ $0.050)$.

The relationship between independence and audit quality is that the value of auditing depends heavily on the public's perception of the auditors' independence. (Arens, Randal, Mark \& Chris, 2017) In this study, audit explains audit quality, so that audit quality is highly dependent on the auditor's perception of the independent auditor. An independent auditor will be honest and objective in considering the evidence in the field so that the audit conducted will result in good audit quality. Although in practice there is always intervention within the auditor or the environment, seeing the object of the Inspectorate's examination is the government environment and is an internal audit, so there is pressure in the form of having to produce quality audits. The influence of independence on audit quality is currently happening because the Inspectorate is a government environment. The West Java Provincial Inspectorate auditor only examines the form of an LKPD review to provide limited assurance on LKPD or recommendations, not in the form of opinions or opinions on financial reports. In addition, the scope of inspection of the Inspectorate of West Java Province will always be the same for each inspection period, this can lead to a kinship relationship between the object of the examination and the auditor, whether consciously or not, this will reduce the independent attitude of an auditor so that the quality of the auditor can decrease.

The Effect of Ethics on Audit Quality. Based on the results of the study as shown in table 2 that Ethics influences Audit Quality, it can be seen that the influence of the X3 variable (Ethics) on the dependent variable Y (Audit Quality) at the Inspectorate of West Java Province partially obtained from Beta x Zero-order is $0.403 \times 0.812=0.327$ or $32.7 \%$. Therefore, at the time of testing the hypothesis to determine the effect of ethics on audit quality, the value of ethics (X3) was obtained, the value of t count (5.768) > t table (1.6676) sig $(0.00)<$ alpha (0.05) so that Ho was rejected, which means that partially the Ethics variable significant effect.

The results of this study are supported by the results of previous studies that have been carried out. In addition, the results of this study are supported by the results of previous studies conducted by Sitorus, Hendratono \& Fransisca (2020) that independence has a significant effect with a significance value of $<0.05$, which is 0.000 . This means that this study partially shows that ethics affect audit quality.

This study supports previous research from Gamayuni (2018), audit quality is a condition where an auditor will find and report discrepancies against the principles in his client's accounting reports. Independence, auditor ethics, competence, and audit standards 
are seen as related to the audit quality produced by the auditor. (Zhukun, Wang \& Zhang, 2018; Alias, Nawawi \& Salin, 2019)

The Code of Ethics at the Inspectorate refers to Article 52 of the Government Regulation of the Republic of Indonesia Number 60 of 2008 requiring AAIPI as a professional organization to prepare a code of ethics for government internal control officers to maintain the behavior of officials who have the task of carrying out supervision and who have fulfilled the competency requirements as internal government auditors. Ethics in the Inspectorate aims to help to act freely but can be accounted for. Therefore, auditor ethics is a very influential factor in determining audit quality to realize a sound supervision system following what has been mandated in the law.

Effect of Expertise, Independence, Ethics on Audit Quality. Simultaneously the influence of expertise, independence, and ethics on audit quality at the West Java Inspectorate in this study, the magnitude of the coefficient of determination (R2) is 0.837 or $83.7 \%$. At the same time, the remaining $16.30 \%$ is influenced by other variables not examined, including Professionalism, Skepticism, and Fraud. The results of this study show that the influence of Expertise, Independence, and Ethics on Audit Quality is more significant than previous studies conducted by Indah \& Erina (2019) and Hikmayah \& Aswar (2019), which showed that expertise, independence, and ethics greatly determine the quality of the resulting audit. By an auditor.

The development of an increasingly advanced era of the global economy guides organizations or institutions to prepare financial reports properly and can be accounted for. This is an essential aspect in an organization because it can be seen the organization's financial condition from the results of financial reports. A financial presentation that is real or able to show the performance of the organization. The financial statements issued must comply with the Financial Accounting Standards regulated by the Indonesian Institute of Accountants (IAI).

The quality of audit service is defined as the market-assessed joint probability that a given auditor will discover a breach in the client's accounting system and report the breach. (Ciger, 2020) Audit quality means how to tell an audit to detect and report material misstatements in financial statements. (Arens, Randal, Mark \& Chris, 2017) The detection aspect reflects auditor competence, while reporting reflects ethics or auditor integrity, particularly independence.

Auditors in carrying out their roles are required to have greater responsibilities. Auditors must be professional, independent, technically qualified, and experienced. The professional attitude of an auditor plays an important role in examining the company's financial statements. In addition, independence is one of the crucial things in producing a quality audit. The importance of independence in producing good audit quality requires the auditor to have and maintain independence in carrying out their duties. Competence also plays an important role in producing a quality audit. Competence is the ability to apply their knowledge in conducting audits so that the auditor can conduct audits carefully and objectively. In addition, work experience is one of the essential things in 
producing a quality audit so that it can expand the knowledge that an auditor already has in carrying out audit activities, expertise is needed with the expertise of an auditor being able to detect errors and then with an attitude of independence in managing audit evidence so that it can be objective, if there is a violation in the auditor's report, it must refer to the ethics of an auditor, namely PP 60 of 2008 so that it will support in producing good quality audits.

\section{CONCLUSION}

Expertise gives the first most dominant influence on audit quality at the Inspectorate of West Java Province. Expertise is the dominant variable because the Inspectorate of West Java Province has a good standard of expertise and carries out expertise following the provisions that exist in the West Java Provincial Inspectorate to impact audit quality.

The independence of being has a third effect on audit quality at the Inspectorate of West Java Province, with a total effect. Auditor independence in examining the West Java Provincial Inspectorate was not born just like that but was more driven by external factors. The influence of the independent variable was not more significant than the expertise and ethics variable at the West Java Provincial Inspectorate.

Ethics contributes the second dominant influence on audit quality at the Inspectorate of West Java Province. Many aspects that determine auditor ethics are listed in the Decree of the Inspector of the West Java Province's code of ethics, audit standards, and internal peer review guidelines of the West Java Province Inspectorate.

In this study, expertise, independence and ethics affect audit quality at the Inspectorate of West Java Province. Further research is needed on the direction of future research on causality and direct and indirect effects between expertise, independence, and ethics as academic and practical implications to confirm the results of the limitations of this study.

\section{REFERENCES}

Adams, M. B. (1994). Agency theory and the internal audit. Managerial auditing journal, 9(8), 8-12. https://doi.org/10.1108/02686909410071133

Afiah, N. N., \& Rahmatika, D. N. (2014). Factors influencing the quality of financial reporting and its implications on good government governance. International Journal of Business, Economics and Law, 5(1), 111-121.

Alias, N. F., Nawawi, A., \& Salin, A. S. A. P. (2019). Internal auditor's compliance to code of ethics: empirical findings from Malaysian government-linked companies. Journal of Financial Crime, 26(1), 179-194. https://doi.org/10.1108/JFC-07-20170066 
Aliu, M. M., Okpanachi, J., \& Mohammed, N. A. (2018). Auditor's Independence and Audit Quality: An Empirical Study. International Accounting and Taxation Research Group. www. arteryview.com.

Andrews, M. (2010). Good government means different things in different countries. Governance, 23(1), 7-35. https://doi.org/10.1111/j.1468-0491.2009.01465.x

Arens, A. A., Randal, J. E., Mark, S. B., \& Chris, E. H. (2017). Auditing and Assurance Service. Sixteenth Edition, Published by Pearson Aducation.

Barzelay, M. (1997). Central audit institutions and performance auditing: A comparative analysis of organizational strategies in the OECD. Governance, 10(3), 235-260.

Bedard, J. C., Johnstone, K. M., \& Smith, E. F. (2010). Audit quality indicators: A status update on possible public disclosures and insights from audit practice. Current Issues in Auditing, 4(1), C12-C19.

Ciger, A. (2020). Audit Quality: A Bibliometric Analysis (1981-2020). Scientific Annals of Economics and Business, 67(4), 473-494.

Eilifsen, A., Messier, W. F., Glover, S. M., Prawitt, D. F. (2014). Auditing \& assurance services. McGraw-Hill: Boston.

Gamayuni, R. R. (2018). The effect of internal auditor competence and objectivity, and management support on effectiveness of internal audit function and financial reporting quality implications at local government. International Journal of Economic Policy in Emerging Economies, 11(3), 248-261.

Head, B. W. (2012). The contribution of integrity agencies to good governance. Policy Studies, 33(1), 7-20.

Hikmayah, N., \& Aswar, K. (2019). The impact of factors on the audit quality in Indonesia: The moderating effect of professional commitments. International Journal of Academic Research in Accounting, Finance and Management Sciences, 9(4), 285-293. DOI: 10.6007/IJARAFMS/v9-i4/6916

Indah, A. T., \& Erina, S. (2019). The role of gender in moderating the effect of competence, independence, and ethics toward audit quality: a case study on finance and development supervision body of East Java Representative. Russian Journal of Agricultural and Socio-Economic Sciences, 87(3), 131-139. DOI: 10.18551/rjoas.2019-03.17

Kallunki, J., Kallunki, J. P., Niemi, L., Nilsson, H., \& Aobdia, D. (2019). IQ and audit quality: Do smarter auditors deliver better audits?. Contemporary Accounting Research, 36(3), 1373-1416.

Lee, S. C., Su, J. M., Tsai, S. B., Lu, T. L., \& Dong, W. (2016). A comprehensive survey of government auditors' self-efficacy and professional Development for improving audit quality. SpringerPlus, 5(1), 1-25. 
Motubatse, K. N., Ngwakwe, C. C., \& Sebola, M. P. (2017). The effect of governance on clean audits in South African municipalities. African Journal of Public Affairs, 9(5), 90-102.

Nor, W., Hudaya, M., \& Novriyandana, R. (2019). Financial statements disclosure on Indonesian local government websites: A quest of its determinant (s). Asian Journal of Accounting Research, 4(1), 112-128. https://doi.org/10.1108/AJAR-062019-0043

Pamungkas, B., Ibtida, R., \& Avrian, C. (2018). Factors influencing audit opinion of the Indonesian municipal governments' financial statements. Cogent Business \& Management, 5(1), 1540256. https://doi.org/10.1080/23311975.2018.1540256

Prawitt, D. F., Smith, J. L., \& Wood, D. A. (2009). Internal audit quality and earnings management. The accounting review, 84(4), 1255-1280.

Radcliffe, V. S. (2008). Public secrecy in auditing: What government auditors cannot know. Critical Perspectives on Accounting, 19(1), 99-126.

Roussy, M., \& Brivot, M. (2016). Internal audit quality: a polysemous notion?. Accounting, Auditing \& Accountability Journal, 29(5), 714-738. https://doi.org/10.1108/AAAJ-10-2014-1843

Sitorus, T., Hendratono, T., \& Fransisca, N. (2020). The Factors Affecting Audit Quality. Journal of Economics, Business, \& Accountancy Ventura, 23(2), 243-253.

Sutaryo, Naviantia, I. A., \& Muhtar (2020). Audit Opinion on Government Financial Report: Evidence from Local Governments in Indonesia. International Journal of Economics \& Management, 14(1), 129-144.

Zhukun, L., Wang, C., \& Zhang, C. (2018). Government Auditors' Ethics Commitment and Audit Quality. Available at SSRN 3217733. 